\title{
Spatial patterns of the Citrus leprosis virus and its associated mite vector in systems without intervention
}

\author{
R. B. Bassanezi ${ }^{a *} \mathbb{D}$, A. B. C. Czermainskib ${ }^{b}$ F. F. Laranjeira ${ }^{c}$, A. S. Moreira ${ }^{C} \mathbb{D}$, \\ P. J. Ribeiro Júnior ${ }^{d}$, E. T. Krainski ${ }^{d}$ and L. Amorim ${ }^{e}$ \\ ${ }^{a}$ Research \& Development Department, Fundecitrus, CP 391, 14801-970 Araraquara, SP; ' Embrapa Grape \& Wine, CP 130, $95700-000$ \\ Bento Gonçalves, RS; ' Embrapa Cassava \& Fruits, 44380-000 Cruz das Almas, BA; ' Department of Statistics, Federal University of \\ Parana, CP 19081, 81531-990 Curitiba, PR; and ${ }^{\mathrm{e}}$ Plant Pathology and Nematology Department, University of Sao Paulo, CP 9, 13418-900 \\ Piracicaba, SP, Brazil
}

Leprosis is caused by the Citrus leprosis virus cytoplasmic type and is vectored by the mite Brevipalpus yothersi. Miticide applications, which cost $\$ 54$ million annually, are based on inspection for the presence of mites. The aim of the present study was to characterize the spatial patterns of $B$. yothersi-infested trees and trees with leprosis symptoms for further improvement in sampling and disease control. The presence of mites and the occurrence of leprosis were assessed over two years in 1160 Valencia trees and 720 Natal trees in a commercial sweet orange grove in Sao Paulo State, Brazil. To assess the natural growth and dispersal of mites and leprosis, mite populations were not controlled during the experimental period. Maps of mite-infested trees and trees with leprosis symptoms were analysed at three different levels of spatial hierarchy using complementary methods, i.e. among adjacent trees within and across rows, within quadrats, and the strength and orientation of aggregation among quadrats. The study showed that the spatial patterns of virus-infected and mite-infested trees were different, with a strong aggregation pattern of trees with leprosis symptoms that increased over time. Conversely, the spatial pattern of $B$. yothersi showed randomness or weak aggregation at all three spatial hierarchical levels. Disease incidence increased steadily in plots of both cultivars, unlike in miteinfested trees where incidence fluctuated over time. These results have important implications for the development of better management strategies for leprosis. Sampling methods and action thresholds for mite control should consider primary disease inoculum in addition to the incidence of mites.

Keywords: Brevipalpus yothersi, Citrus leprosis virus, Citrus sinensis, epidemiology, flat mite, spatial analysis

\section{Introduction}

Leprosis is considered to be the most critical virus disease in the Brazilian citrus industry because it causes severe yield losses and reduction in the lifespan of trees, especially in the sweet orange (Citrus sinensis; Bastianel et al., 2010). Historically, the occurrence of Citrus leprosis virus was restricted to a few countries in South America, i.e. Argentina, Uruguay, Paraguay and Brazil. However, since 2000 the disease has spread to other countries throughout the South, Central and North Americas and has become a threat to citrus production (Bastianel et al., 2010; Roy et al., 2015). Thus, there has been an increased requirement for better management of leprosis in the Americas.

The disease is mainly caused by the cilevirus Citrus leprosis virus cytoplasmic type (CiLV-C; Locali-Fabris

*E-mail: renato.bassanezi@fundecitrus.com.br

Published online 4 September 2018 et al., 2011), which is transmitted by mites of the genus Brevipalpus (Acari: Tenuipalpidae). In Brazil, B. yothersi (synonym B. phoenicis citrus type) (Beard et al., 2015) is recognized as the main vector of CiLV-C and is the most common species in citrus groves (Sánchez-Velázquez et al., 2015). Virus acquisition by the mite occurs in less than $4 \mathrm{~h}$, with a latent period between acquisition and inoculation of $7 \mathrm{~h}$ (Tassi et al., 2017). The transmission efficiency of CiLV-C by B. yothersi in the sweet orange is $50 \%$ for larvae, $12 \%$ for nymphs, and only $10 \%$ for adult mites (Chagas et al., 1983; Rodrigues, 1995). Unlike other plant viruses, infection by CiLV-C is never systemic and leprosis damage results from local infections of CiLV-C. Leaf and fruit spots, premature leaf and fruit drop, and branch dieback caused by CiLV-C may seriously jeopardize not only the yield but also the tree itself. Depending on the scion variety, without proper management crop loss can reach 100\% (Rodrigues et al., 1994, 2000).

The approach for leprosis management is via mite control using miticide sprays. Depending on the miticide and weather conditions, one to three sprays are applied per growing season, which represent approximately $5 \%$ of 
phytosanitary costs of an adult sweet orange grove in Sao Paulo State, Brazil (Bassanezi, 2017). A complementary control strategy is the elimination of fruits and branches with symptoms. The disease is nonsystemic; therefore, the vector can only acquire the virus by feeding on leprosis lesions (Kitajima et al., 1972; Colariccio et al., 1995). Nevertheless, depending on disease incidence, the elimination of fruits and branches with symptoms can be a laborious and more expensive practice than the application of miticide sprays (Andrade et al., 2013).

The decisions behind application of miticide sprays have been based on systematic and frequent identification of the presence of $B$. yothersi mites on three to five fruits or on terminal branches of $1-2 \%$ of trees in each citrus grove (Salva, 1994; Busoli, 1995; De Negri, 1995; Festuccia et al., 1995; Pinto et al., 1995; Rossetti et al., 1997). There is no scientific evidence of a correlation between total B. yothersi population and leprosis incidence. Thus, advised threshold action levels for spraying have been based on empirical thresholds. Thresholds may vary from $2 \%$ to $15 \%$ of fruit or terminal branches with at least one mite (Nascimento et al., 1982; Busoli, 1995; De Negri, 1995; Pinto et al., 1995; Rossetti et al., 1997; Gravena, 1998, 2000) regardless of CiLV-C presence. Once the decision threshold is reached, growers are advised to spray over the entire grove (Pinto et al., 1995; Rossetti et al., 1997). Such decision thresholds assume that sampled mites have high transmission efficiency and that the inoculum sources are uniformly distributed within the grove. Spraying miticides in the entire grove might lead to environmental risks, suppression of the natural enemies of the vector, high selection pressure for miticide spray resistance, as well as increased production costs.

Leprosis incidence increases significantly from one cycle to the next, which is a typical feature of polyetic diseases; however, it is not associated with previous records of the mite populations (Czermainski et al., 2007). In a previous study undertaken in several commercial groves with mite control, Bassanezi \& Laranjeira (2007) observed that spatial patterns of leprosis symptoms and mite-infested trees were different, i.e. leprosisinfected trees were highly aggregated whereas the aggregation pattern of mite-infested trees was weak. The authors suggested that the spatial discontinuity of the leprosis mite population could be a consequence of the mite sampling method used and frequent miticide spray application. However, the lack of association between mite-infested trees and trees with leprosis symptoms could also be a methodological artefact because only one simultaneous assessment of trees with leprosis symptoms and mite-infested trees was conducted per citrus grove. For that reason, long-term evaluations in untreated groves containing trees with leprosis symptoms and $B$. yothersi-infested trees are required. The aims of the present study were to: (i) characterize and understand the relationship between spatial mite infestation and disease incidence; and (ii) model spatiotemporal patterns of mites and disease during a 2-year period in sweet orange groves in Sao Paulo State without any intervention on mite population or on inoculum sources. Results from the present study will assist in improving disease monitoring and management programmes, especially for the development of effective sampling schemes for the disease and mites.

\section{Materials and methods}

The incidence of leprosis symptoms and B. yothersi infestation were assessed in two plots located within a grove planted in 1996 in Santa Cruz do Rio Pardo, western Sao Paulo State, Brazil $\left(22^{\circ} 54^{\prime} \mathrm{S}, 4^{\circ} 25^{\prime} \mathrm{W}\right)$. Both plots were planted with sweet orange cultivars Valencia (plot PV) and Natal (plot PN), grafted on Rangpur lime (Citrus limonia), with a spacing of $7.5 \mathrm{~m}$ (between rows) $\times 3.8 \mathrm{~m}$ (between trees). Plot PV included 1160 trees distributed in 20 rows containing 58 trees each, whereas plot PN included 720 trees distributed in 24 rows containing 30 trees each (Fig. S1). Data were collected over a 2-year period (from December 2002 to October 2004), on a fortnightly or monthly basis, without prejudice to the data collection and analysis performance. Forty-four assessments (44 dates) were performed on every tree in each plot. During the assessment period, all cultural practices were followed as usual, except for the application of miticide sprays that were suspended. Disease incidence was determined by visual assessment of typical leprosis symptoms in 100 fruits, 100 leaves and 100 twigs arbitrarily selected around each tree. The presence of $B$. yothersi was assessed on each tree by examining five fruits inside the canopy and five terminal twigs on the outer part of the canopy using a $\times 10$ magnifying glass. Trees were classified as with symptoms (1) or symptomless (0), and mite-infested (1) or not infested (0). Maps of trees with leprosis symptoms and B. yothersi-infested trees were drawn for each assessment. The sample size was higher than the normal standard sample size used for sampling B. yothersi in sweet orange groves in Brazil (Festuccia et al., 1995; Rossetti et al., 1997).

The spatial patterns of trees with leprosis symptoms and miteinfested trees were analysed at three levels of spatial hierarchy. In the first level, which was based on point pattern analysis, join count analyses were performed on each dataset to determine whether aggregation existed among adjacent trees within and across rows. In the second level, the aggregation hypothesis was examined within quadrats of two sizes and, for the third level, the strength and orientation of aggregation among quadrats were examined using spatial autocorrelation.

For the first level of spatial hierarchy, join count analysis was performed using an ad hoc Python script available at https:// github.com/fflaranjeira/JoCoPy. The algorithms were based on equations provided by Cliff \& Ord (1981) assuming a non-freesampling without replacement, i.e. a category type in one location affects the category type in other locations. It also allows different choices of neighbourhood (i.e. adjacency patterns) or spatial range. Two adjacency patterns were considered, within and across rows, and the degree of spatial association was measured up to the sixth lag. Following the usual terminology for this technique, trees with symptoms or that were mite-infested were assigned to the 'black' (B) category, whereas symptomless or noninfested trees were considered 'white' (Fortin \& Dale, 2007). For each combination of neighbourhood and spatial lag, the expected number of black-black $(\mathrm{BB})$ joins $\left[E_{\mathrm{R}}(\mathrm{BB})\right]$ and standard deviations $\left[s_{R}(B B)\right]$ were calculated, and the observed number of $\mathrm{BB}$ joins was determined. The sample size was 
considered large enough in both areas; therefore, a standard normal statistic $\left[Z(B B)=B B-E_{R}(B B)+0.5 / s_{R}(B B)\right]$ was used to test the departure from complete spatial randomness (Fortin \& Dale, 2007; Madden et al., 2007). Hence, results higher than 1.64 were considered an indication of aggregation $(P<0.05)$. Based on the results for each plot and evaluation, the average $Z(B B)$ value was determined for both disease incidence and mite infestation at each spatial lag.

The minimum mean distance test (MMDIST) was used as an additional analysis for the first level of spatial hierarchy. This analysis is based on the autologistic model, which considers the status of the trees as a binary answer ( 1 or 0$)$. In sequence, the regression coefficients provide an estimation of the increase in probability of disease presence or absence. In this analysis, the neighbourhood may be structured in adjacent trees in the same row or in adjacent rows. Thus, considering neighbours in the same row and neighbours in rows apart, the dispersion of the 'disease degree' is obtained in different directions (Krainski et al., 2006). The function calculates the minimum mean distance among trees with incidence 1 for trees with symptoms or infested trees. The mean number of neighbouring symptoms/ infested test (NNEIGH) was applied to the dataset. The mean number of adjacent trees with symptoms or infested $(x)$ at three different radii was calculated for each tree $(y): 4 \mathrm{~m}-$ the two immediately neighbouring trees within the same row; $7.55 \mathrm{~m}-$ the two adjacent trees within the same row and the two neighbouring trees in adjacent rows; and $8.5 \mathrm{~m}-10$ neighbouring trees (four within the same row and three in each adjacent row). The null hypothesis of complete spatial randomness was tested with $P$ values given by the proportion of MMDIST and NNEIGH computed from 999 simulations under the null hypothesis that were greater than the values estimated from the data. These two tests are variations of the plant disease analysis that is commonly applied in point process analysis (Diggle, 2014). The $\mathrm{R}$ software package used for this analysis was RCITRus (Krainski et al., 2006).

In the second level of spatial hierarchy analysis, grids of $3 \times 3$ trees (quadrat size) were imposed on each plot. The proportions of infested trees or trees with symptoms were determined for each quadrat and the disease/infestation incidence was calculated, as well as the observed variance $\left(V_{\text {obs }}\right)$ and the binomial variance $\left(V_{\text {bin }}\right)$. Then, the index of dispersion $\left(D=V_{\text {obs }} / V_{\text {bin }}\right)$ was calculated and the Taylor's binary power law was applied (Madden \& Hughes, 1995). The significance of $D$ was verified by the $\chi^{2}$ test. $D$-values statistically not different to 1 were considered an indication of randomness, whereas $D>1$ was taken as an indication of clustering. Taylor's binary power law, using linear regression, relates the observed and expected binomial variance (Madden \& Hughes, 1995). Regressions were performed by the least squares method with $\log \left(V_{\text {bin }}\right)$ as the independent factor and $\log \left(V_{\text {obs }}\right)$ as the dependent factor. The regression significance was determined by the $F$ test, and the adequacy of model fitting was established by means of coefficient of determination $\left(R^{2}\right)$ and existence of residual patterns in graphics of residuals versus predicted values of $\log \left(V_{\text {bin }}\right)$ (Madden \& Hughes, 1995). For binary power law, log $\left(V_{\text {obs }}\right)=\log (A)+b \log \left(V_{\text {bin }}\right), A$ and $b$ are parameters. Using estimated parameter values and standard errors, it was tested $(t$ test) whether $b=1$ and $\log (A)=0$. The dataset pattern was considered to be random if $b=A=1$. There is a constant level of aggregation regardless of the incidence when $b=1$ and $\log$ $(A)>0$. When $b>1$, parameter $b$ is considered an aggregation index and the aggregation level varies according to the incidence (Madden \& Hughes, 1995). The equations of binary power law obtained for mite-infested trees and trees with leprosis symptoms in all citrus blocks were compared by coincidence ( $F$-test) and parallelism ( $t$-test) tests.

The third level of spatial hierarchy was examined by spatial autocorrelation analysis, using the LCOR2 software program (Gottwald et al., 1992). Data of trees with leprosis symptoms and mite-infested trees were organized in a matrix of $2 \times 2$ quadrat sizes. The spatial position of each quadrat as well as the measure of infestation/disease intensity were used as input data. The infestation/incidence measure was calculated as the total number of infested trees/trees with symptoms within a given quadrat. LCOR2 uses the Modjeska and Rawlings model (Gottwald et al., 1992), which considers that pairs of observations or counts that share the same spatial relationship have the same correlation. Furthermore, autocorrelation proximity patterns were calculated and consisted of positive $(\mathrm{SL}+)$, negative (SL-), and noncorrelated lag positions, and then the spatial patterns of mite/leprosis symptoms were evaluated. The size of the core clusters of SL+ was calculated, considering that a core cluster is a group of significant, positively correlated $(P=0.01)$ spatial lag distance classes that form a discrete and contiguous group with the origin (i.e. lag $[0,0]$ ) of the autocorrelation proximity pattern. Row effects were evaluated as the proportion of SL+ within the first row (within) or within the first column (across) of the autocorrelation proximity pattern that is contiguous with the origin. The edge effect was evaluated as the proportion of SL+ at the distal edges of the proximity pattern. The proportion of $\mathrm{SL}+$ was plotted over time to verify whether there were changes in mite and leprosis spatial patterns with time.

\section{Results}

The field maps depicting the experimental plots are presented as supplementary figures (Figs S2 \& S3). At the first level of spatial hierarchy, mean $Z(B B)$ values for trees with leprosis symptoms in plot PV was always higher than 1.64, regardless of the adjacency pattern or spatial lag, indicating aggregation within and across rows (Fig. 1a,c). However, these values tended to decrease from the first spatial lag onwards and were higher in the within-rows direction. In plot $\mathrm{PN}$, a decreasing pattern was also observed; however, mean values were significantly higher $(P<0.05)$ than 1.64 only for the first lag (across rows) or up to the second spatial lag (within rows), and were lower than those recorded for plot PV (Fig. 1b,d).

Generally, the $Z(\mathrm{BB})$ values for mite-infested trees were lower than those for trees with leprosis symptoms, irrespective of adjacency pattern or spatial lag (Fig. 1). Mean $Z(\mathrm{BB})$ values were never higher than 1.96 for plot $\mathrm{PN}$. Conversely, in plot $\mathrm{PV}$ the mean $Z(\mathrm{BB})$ value was significantly higher than the threshold for every spatial lag in the within-rows direction. Across rows, only the first two spatial lags had mean $Z(B B)$ values that were higher than 1.96. Mean $Z(B B)$ values for infested trees oscillated during the 2-year period, especially in plot PV (Fig. 2a). Mean $Z(\mathrm{BB})$ values for trees with leprosis symptoms increased during the 2-year period in both plot PV and plot PN (Fig. 2b).

The proportion of the minimum mean distance and the mean number of neighbouring infested trees/trees 


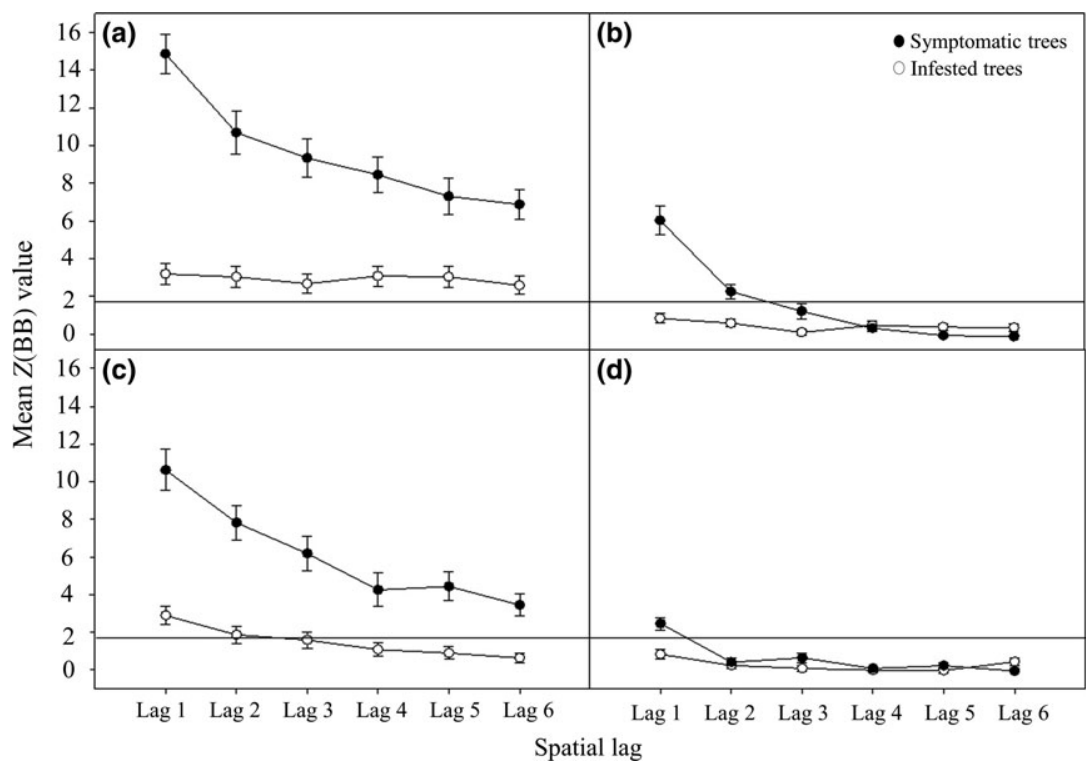

Figure 1 Join count results for Brevipalpus yothersi mites and leprosis symptoms in two plots, two directions, and six spatial lags of sweet orange Valencia and Natal. Plot Valencia (PV) within rows (a), plot Natal (PN) within rows (b), plot Valencia (PV) across rows (c), and plot Natal (PN) across rows (d). Points represent medium Z(BB) values for each spatial lag considering all evaluations and bars represent standard errors. In each graph, the horizontal line represents the value above which $Z(B B)$ values denote aggregation $(P<0.05)$.
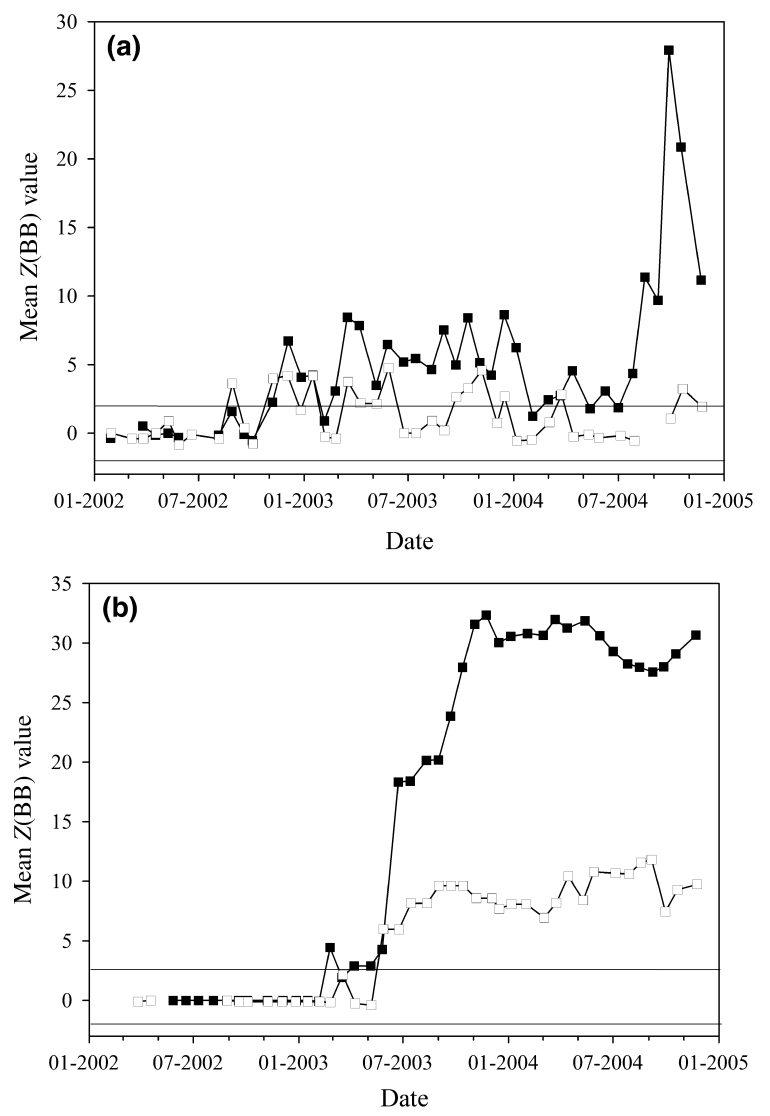

Figure 2 Join count results for Brevipalpus yothersi mites and leprosis symptoms in two plots of sweet orange Valencia and Natal over a 2year period. Mite-infested trees (a) and trees with leprosis symptoms (b) at plot Valencia (PV) (black squares) and plot Natal (PN) (white squares). Points represent average $Z(B B)$ values for all evaluations. In each graph, the horizontal line represents the value above which $Z(B B)$ values denote aggregation $(P<0.05)$. with symptoms both tested at a significance of 0.05 $(P<0.05)$, represented by white triangles and right $y$ axes in Figure 3, which was associated with the minimum mean distance among mite-infested trees varying over time in plot PV. Values were greater than 0.10 for most evaluations, indicating randomness of miteinfested trees (Fig. 3a). Patterns of trees with leprosis symptoms showed significant MMDIST values $(P<0.05)$, i.e. the minimum mean distance among trees with leprosis symptoms was lower than expected. As the disease incidence increased ( $x$-axis), the MMDIST between trees with leprosis symptoms decreased, i.e. the disease aggregation increased (Fig. 3b). There was a linear increase in the mean number of neighbouring miteinfested trees as the number of infested trees increased in plot PV, regardless of the radius (4.0, 7.55 and $8.5 \mathrm{~m})$. The mean number of neighbouring trees with leprosis symptoms remained stable even with the increase in the incidence of trees with leprosis symptoms. There was no consistent pattern between these variables in plot PN (Fig. 4).

At the second level of spatial hierarchy, $D$ showed alternation between randomness and aggregation patterns for mite-infested trees in PV and PN plots, with predominance for aggregation (Fig. 5). Especially in the PN plot, there was no clear relationship between $D$ values and the incidence of mite-infested trees (Fig. 5b). At low incidence levels of trees with leprosis symptoms (up to 0.05 for plot PV and 0.02 for plot PN), D values showed an increase in aggregation of trees with leprosis symptoms with an increase in disease incidence (Fig. 5). $D$ values were usually higher for trees with leprosis symptoms than for mite-infested trees (Fig. 5). The parameters of Taylor's binary power law, $A$ and $b$, were significantly different from 0 and 1 , respectively $(P<0.05)$, indicating an aggregation pattern that increases with the increase of incidence of both mite- 
Figure 3 Mite-infested trees (proportion) (a) and trees with leprosis symptoms (proportion) (b) at different minimum mean distance (black triangles) and related $P$ values (white triangles) in plot Valencia (PV) experimental grove. In each graph, the horizontal line represents the value below which $P$ values denote aggregation $(P<0.05)$.

Figure 4 Mean number of infested trees or neighbour trees with leprosis symptoms in relation to mite-infested trees (proportion) at plot Valencia (PV) (a) and plot Natal (PN) (b) and mean number of trees with leprosis symptoms (proportion) at plot Valencia (PV) (c) and plot Natal (PN) (d) based on an analysis over a radius of $8.5 \mathrm{~m}$.
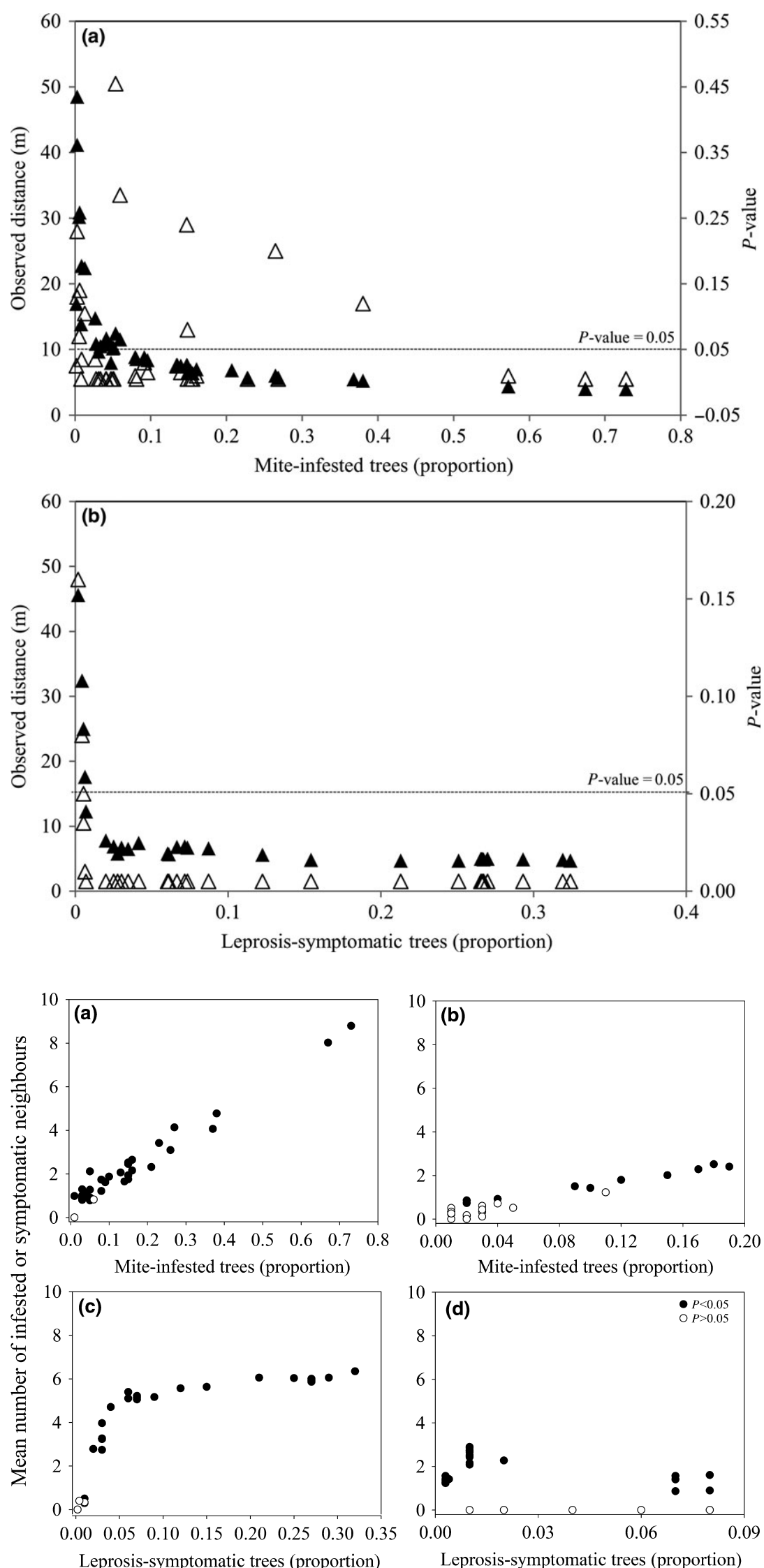

Leprosis-symptomatic trees (proportion) 


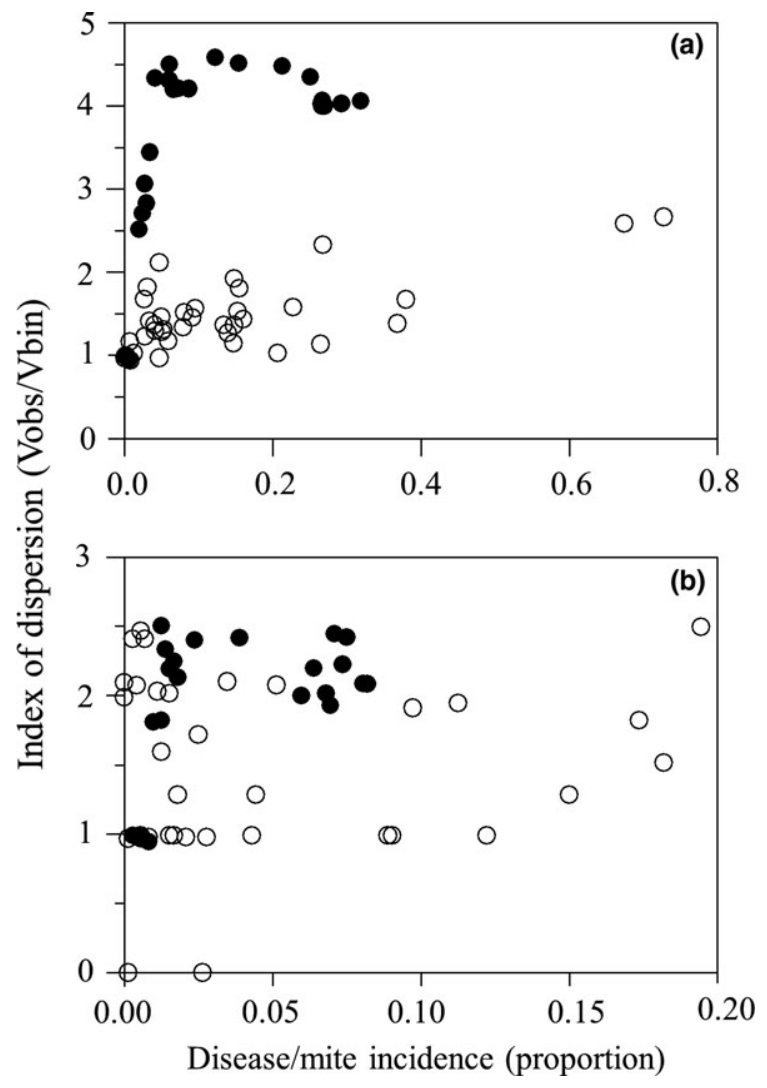

Figure 5 Scatterplot of mite-infested trees (open circles) incidence (proportion) versus index of dispersion $(D)$ obtained in $3 \times 3$ quadrats and trees with leprosis symptoms (closed circles) incidence versus $D$, in plot Valencia (PV) (a) and plot Natal (PN) (b).

infested trees and trees with leprosis symptoms (Fig. 6). For plot PV, the regression slope of trees with leprosis symptoms (Fig. 6c) was steeper than that for incidence of mite-infested trees (Fig. 6a), indicating a higher aggregation level for trees with leprosis symptoms than for mite-infested trees.

No edge effects were detected in the third level of spatial hierarchy in any evaluation. The proportion of SL+ for mite-infested trees increased with incidence, but in a scattered way, especially for plot PV (Fig. 7a). Conversely, for trees with leprosis symptoms, there was a consistent linear increase in SL+ as incidence of trees with leprosis symptoms increased, especially in plot PV (dark circles; Fig. 7c). The proportion of core cluster SL+ in the within-rows direction was always higher than the proportion across rows, regardless of the evaluation, experimental plot, or variable applied. The number of core cluster SL+ tended to oscillate for mite-infested trees (Fig. 7b) and increase for trees with leprosis symptoms in plot PV (Fig. 7d). The mean size of core clusters in plot PN did not vary significantly over the course of the experiment, with low values of $\mathrm{SL}+$ for both miteinfested trees and trees with leprosis symptoms. The proportion of SL+ for mite-infested trees and trees with leprosis symptoms was different (Fig. 8), i.e. for miteinfested trees the proportion of SL+ oscillated during the evaluation period (Fig. 8a) whereas for trees with leprosis symptoms the proportion of SL+ increased over time, especially in plot PV (Fig. 8b).

\section{Discussion}

To the best of the authors' knowledge, this is the first study to monitor the spatial progress of CiLV-C and its vector $B$. yothersi over time in a system without intervention. The spatial patterns of mite-infested trees and trees with leprosis symptoms were characterized at 44 dates over a 2-year period. A previous study on the same subject was based on only one simultaneous assessment of the incidence of $B$. yothersi-infested trees and trees

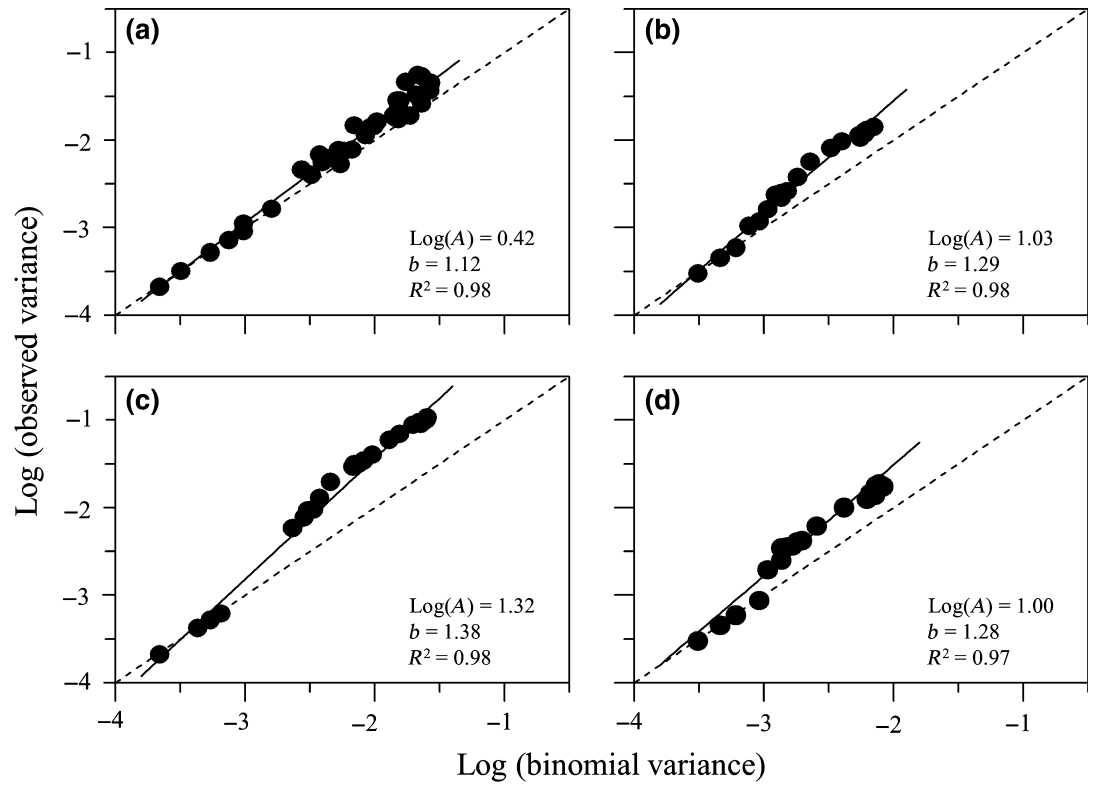

Figure 6 Relationships between the logarithm of the observed and theoretical binomial (random) variance of incidence of mite (Brevipalpus yothersi) infested citrus trees ( $\mathrm{a}$ and $\mathrm{b}$ ) and trees with leprosis symptoms (Citrus leprosis virus) (c and d) in plots of Valencia ( $a$ and $c$ ) and Natal (b and d). Each data point represents an assessment and the solid lines represent the relationship $\log \left(V_{\text {obs }}\right)=\log (A)+b \log \left(V_{\text {bin }}\right)$ fitted to the data by ordinary least squares regression using a $3 \times 3$ quadrat size. The dashed lines represent the binomial line (i.e. observed variance = binomial variance) . 

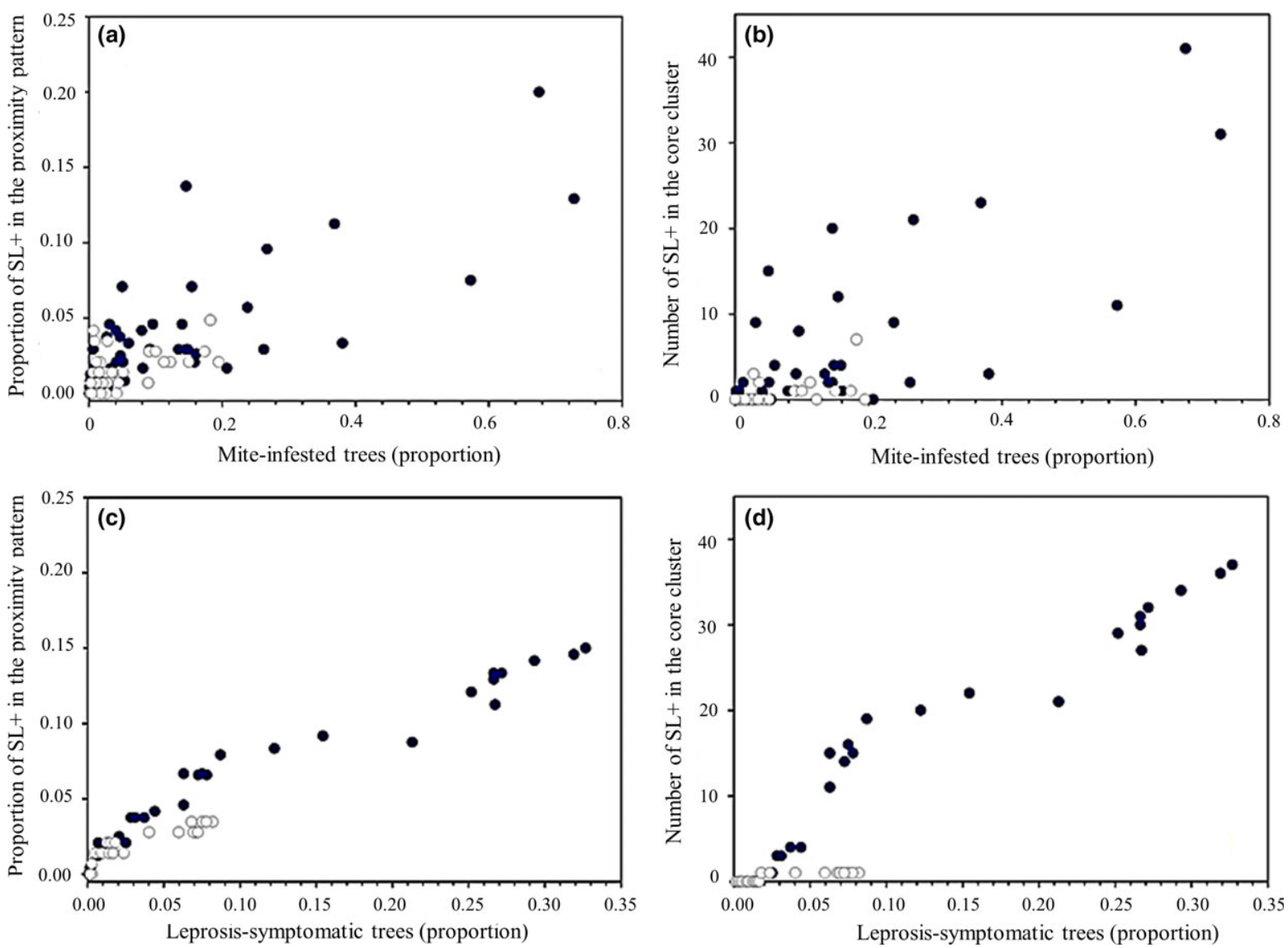

Figure 7 Proportion of $S L+$ in the proximity pattern $(a, c)$ and number of $S L+$ in the core cluster $(b, d)$ according to incidence of trees with leprosis symptoms or mite-infested trees in plots of sweet orange Valencia (dark circles) and Natal (white circles) in Sao Paulo, Brazil. [Colour figure can be viewed at wileyonlinelibrary.com].

with leprosis symptoms in commercial groves (Bassanezi \& Laranjeira, 2007). There are relevant differences in the management of mite populations between these studies. The present study was undertaken in an untreated system with no miticide spray application or removal of inoculum sources. In contrast, Bassanezi \& Laranjeira (2007) studied the pathosystem in groves with chemical management for mite control and without successive assessment of disease incidence and mite infestation over time. Other studies have focused either on spatial distribution of citrus leprosis (Oliveira Junior et al., 2016) or on spatial distribution of the mite vector (Maldonado Junior et al., 2016). Despite CiLV-C dispersal being totally vector-dependent, the spatial pattern of miteinfested trees and trees with leprosis symptoms were not similar. The three levels of spatial hierarchy used in the present study indicated that the disease pattern was not associated with that of the B. yothersi population, which was random or weakly aggregated in almost all assessments.

The plausible reason for this lack of association between mite-infested trees and trees with leprosis symptom is that the sampling method for monitoring the vector did not distinguish between viruliferous and non-viruliferous mites. Furthermore, the small size of $B$. yothersi makes it difficult to locate them when they occur at low incidences (Bassanezi \& Laranjeira, 2007), even when using samples sizes larger than the standard, i.e. the presence of $B$. yothersi mites on three to five fruits or on terminal branches of $1-2 \%$ of trees in each citrus plot. In addition, B. yothersi is a low mobility mite and the wind may affect its dispersal (Alves et al., 2005). The wind direction might have favoured greater mite dispersion in the plot with Valencia due to the rows facing in an east-west direction, which was different from the plot with Natal in which the rows acted as a wind barrier. Moreover, trees in the plot with Valencia had a higher canopy volume than trees in the plot with Natal, which favoured contact between the canopies and contributed to the mite tree-to-tree crawling movement in the rows direction.

The aggregation pattern of trees with leprosis symptoms was common at the three levels of spatial hierarchy. This disease aggregation pattern has also been reported in previous studies using similar spatial analyses (Bassanezi \& Laranjeira, 2007) or geostatistical analysis (Maldonado Junior et al., 2016). Conversely, the spatial pattern of $B$. yothersi-infested trees (unknown infection 

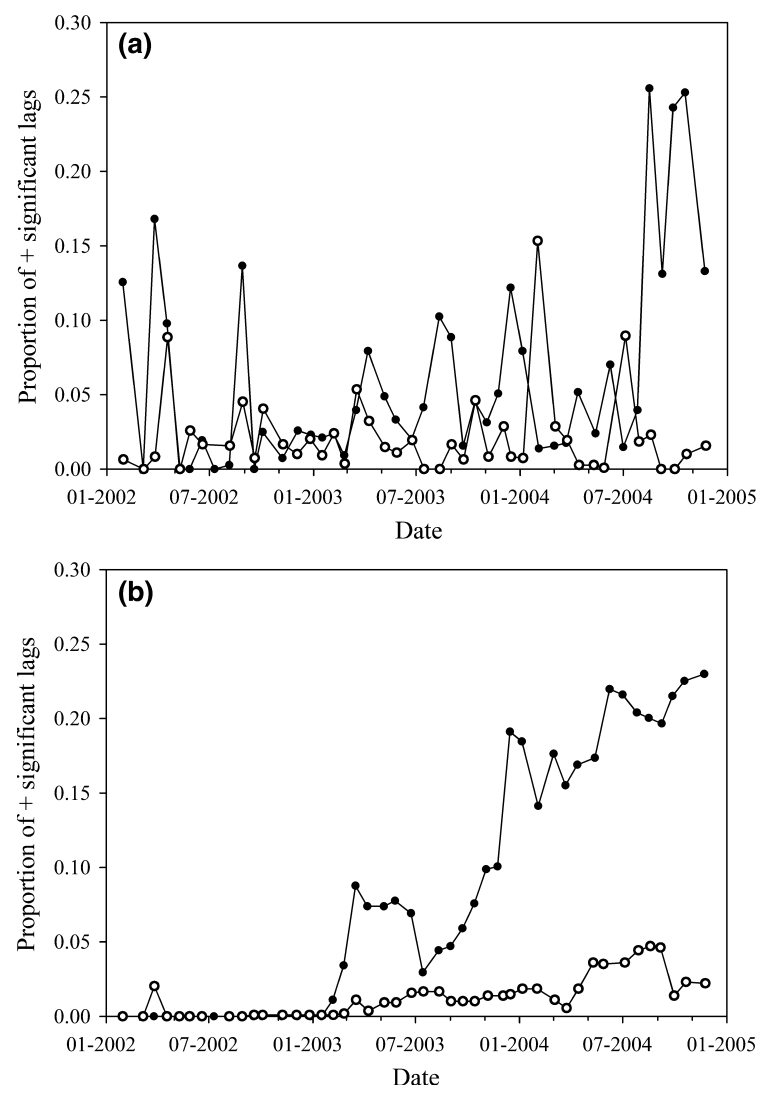

Figure 8 Proportion of SL+ significant lags in mite-infested trees (a) and in trees with leprosis symptoms (b) over a 2-year period in plots of sweet orange Valencia (dark circles) and Natal (white circles) in São Paulo, Brazil.

status) was predominantly random in all levels of spatial hierarchy, where $Z(\mathrm{BB})$ values were lower than those for trees with leprosis symptoms and random for the major lags. The randomness was also indicated in MMDIST, and $D$, as well as in the parameters $A$ and $b$ of Taylor's binary power law. The autocorrelation spatial analysis of the mite-infested trees spatial pattern was not consistent with the trees with leprosis symptoms spatial pattern. This finding is in contrast with results from other studies that have reported an aggregated spatial pattern of miteinfested trees (Maldonado Junior et al., 2016).

Based on Taylor's power law parameters, the results here showed that the aggregation pattern of trees with leprosis symptoms is stronger than that for other citrus diseases, such as citrus variegated chlorosis (CVC) vectored by sharpshooters (Laranjeira et al., 2004) or citrus canker that is typically spread by water and wind (Bergamin Filho et al., 2000), in which the strength of aggregation of trees with symptoms was not the same as that of trees with leprosis symptoms. Flavescence dorée, a phytoplasma disease of grapevines, also shows aggregated spatial patterns that are associated with the short-distance mobility of the vector. Similar to the results here, the spread of flavescence dorée was shown to be predominantly along rows (Maggi et al., 2017).

The results from the present study confirm that the presence or absence of mites is not a sufficient criterion for making inferences about the risk of CiLV-C occurrence because the sampling methodology does not allow differentiation between viruliferous and nonviruliferous mites. Not all mites exposed to an infected source become viruliferous, probably owing to a lack of access to the infected tissues present only in the lesions, and by the inability of the virus to cross the midgut and/or anterior podocephalic gland barrier, thus disabling the inoculation (Tassi et al., 2017). Hence, the decision as to whether or not to apply miticide spray cannot be based solely on the monitoring of mite populations. Information regarding the aggregated pattern of diseased trees reported in the present study should be considered in an effort to improve miticide spray application in groves with high leprosis incidence.

Alternative mite sampling strategies have been reported in previous studies to improve the disease control strategy, yet the CiLV-C spatial pattern has not been contemplated (Maldonado Junior et al., 2016). In sweet orange commercial groves, precise estimations of leprosis incidence are difficult to calculate and depend on specific sampling plans designed for a highly aggregated disease pattern. The analyses carried out in the present study provide support for the development of better sampling methodologies for citrus leprosis management, based on the incidence of the disease.

Identification of the original disease foci appears to be a good control strategy, as the management can be restricted to focus trees and a radius of neighbouring trees that might be infected, but that are symptomless because mites might retain and transmit the virus for up to 10 days (Tassi et al., 2017). This strategy might be useful for spraying miticides and removing branches with symptoms at the initial foci. In commercial groves, monitoring could be directed to branches and fruits with symptoms instead of only to mite populations. Detection of trees with leprosis symptoms could be performed during monthly inspections and additionally during surveys that are routinely performed for huanglongbing in groves from Sao Paulo, Brazil. Arguably, this would increase the efficiency of citrus leprosis management without increasing the cost of sampling the grove.

\section{Acknowledgements}

The authors acknowledge the Brazilian National Council for Scientific and Technological Development (CNPq) and the São Paulo Research Foundation (FAPESP) for financial support (project no. 06/01162-0).

\section{References}

Alves EB, Casarin NFB, Omoto C, 2005. Mecanismos de dispersão de Brevipalpus phoenicis (Geijskes, 1939) (Acari: Tenuipalpidae) em pomares de citros. Neotropical Entomology 34, 89-96. 
Andrade DJ, Pattaro FC, Morais MR, Barbosa CL, de Oliveira CAL, 2013. Aspectos técnicos e econômicos da poda e do controle químico de Brevipalpus phoenicis no manejo da leprose dos citros. Revista Brasileira de Fruticultura 35, 409-24.

Bassanezi RB, 2017. Leprose dos citros: medidas essenciais de controle. Fundecitrus, 2nd edn. [http://www.fundecitrus.com.br/comunicacao/ download_manual/50]. Accessed 18 September 2017.

Bassanezi RB, Laranjeira FF, 2007. Spatial patterns of leprosis and its mite vector in commercial citrus groves in Brazil. Plant Pathology 56 , 97-106.

Bastianel M, Novelli VM, Kitajima EW et al., 2010. Citrus leprosis: centennial of an unusual mite virus pathosystem. Plant Disease 94, 284-92.

Beard JJ, Ochoa R, Braswell WE, Bauchan GR, 2015. Brevipalpus phoenicis (Geijskes) species complex (Acari: Tenuipalpidae) - a closer look. Zootaxa 3944, 1-67.

Bergamin Filho A, Hau B, Amorim L, Laranjeira FF, Gottwald TR, 2000. Epidemiology of citrus canker in Brazil with and without the Asian Citrus leafminer. In: Gottwald TR, Levy L, Dixon WN, eds. Proceedings of the International Citrus Canker Research Workshop, 2000. Tallahassee, FL, USA: Florida Department of Agriculture and Consumer Services, 6.

Busoli AC, 1995. O manejo integrado de pragas - citros e a busca de qualidade total na citricultura. Laranja $16,155-86$.

Chagas CM, Rossetti V, Chiavegato LG, 1983. Effectiveness of the different life cycle stages of Brevipalpus phoenicis Geijskes in leprosis transmission. In: Proceedings of the International Organisation of Citrus Virologists. Riverside, CA, USA: IOCV, 211-4.

Cliff AD, Ord JK, 1981. Spatial Processes - Models and Applications. London, UK: Pion.

Colariccio A, Lovisolo O, Chagas CM, Galleti SR, Rossetti V, Kitajima EW, 1995. Mechanical transmission and ultra-structural aspects of citrus leprosis disease. Fitopatologia Brasileira 20, 208-13.

Czermainski ABC, Bassanezi RB, Laranjeira FF, Amorim L, 2007. Dinâmica temporal da população do ácaro Brevipalpus phoenicis e da leprose dos citros sob condições naturais de epidemia. Fitopatologia Brasileira 32, 295-303.

De Negri JD, 1995. MIP- Citros no estado de São Paulo. In: Oliveira CAL, Donadio LC, eds. Leprose dos Citros. FUNEP: Jaboticabal, Brazil, 105-16.

Diggle PJ, 2014. Statistical Analysis of Spatial and Spatio-temporal Point Patterns. 3rd edn. Chapman \& Hall/CRC Monographs on Statistics \& Applied Probability. Boca Raton, FL, USA: CRC Press.

Festuccia AJ, de Almeida MC, Yamamoto PT, Gravena S, 1995. Comparação entre amostragens absoluta e relativa para o ácaro da leprose em citros. Laranja 16, 263-70.

Fortin MJ, Dale M, 2007. Spatial Analysis: A Guide for Ecologists. Cambridge, UK: Cambridge University Press.

Gottwald TR, Richie SM, Campbell CL, 1992. LCOR2 - spatial correlation analysis software for the personal computer. Plant Disease 76, 213-5.

Gravena S, 1998. Manejo ecológico de pragas dos citros - aspectos práticos. Laranja 19, 61-77.

Gravena S, 2000. Manejo integrado de pragas dos citros no contexto de citricultura integrada. Seminário Internacional de Citros, Bebedouro. Bebedouro, Brazil: Fundação Cargill, 147-75.

Kitajima EW, Muller GW, Costa AS, Yuki W, 1972. Short, rod-like particles associated with citrus leprosis. Virology 50, 254-8.

Krainski ET, Ribeiro Junior PJ, Bassanezi RB, 2006. RcrTRus: software para análise estatística de dados de incidência de doenças em plantas. [http://www.leg.ufpr.br/Rcitrus/]. Accessed 3 March 2015.

Laranjeira FF, Bergamin Filho A, Amorim L, Gottwald TR, 2004. Dinâmica espacial da clorose variegada dos citros em três regiões do Estado de São Paulo. Fitopatologia Brasileira 29, 56-65.

Locali-Fabris EC, Freitas-Astúa J, Machado MA, 2011. Genus Cilevirus. In: King A, Adams M, Carstens E, Lefkowitz E, eds. Virus Taxonomy
- Ninth Report of the International Committee on Taxonomy of Viruses, 2011. London, UK: Elsevier Academic Press, 1139-42.

Madden LV, Hughes G, 1995. Plant disease incidence: distributions, heterogeneity, and temporal analysis. Annual Review of Phytopathology 33, 529-64.

Madden LV, Hughes G, van den Bosch F, 2007. The Study of Plant Disease Epidemics. St Paul, MN, USA: APS Press.

Maggi F, Bosco D, Galetto L, Palmano S, Marzachi C, 2017. Space-time point pattern analysis of flavescence dorée epidemic in a grapevine field: disease progression and recovery. Frontiers in Plant Science 7, 1987.

Maldonado Junior W, Barbosa JC, Costa MG, Gonçalves PCT, Santos TR, 2016. Spatial distribution and sequential sampling of Brevipalpus phenicis in citrus. Revista Brasileira de Fruticultura 38, 1-9.

Nascimento AS, Morais GJ, Cabrita JRM et al., 1982. Manual de Manejo Integrado das Pragas do Pomar Cítrico. Cruz das Almas, Brazil: EMBRAPA-CNPMF. Documentos, 6.

Oliveira Junior F, Farias PRS, Silva AG, Rodrigues KCV, Araújo FCB, 2016. Spatial distribution of citrus leprosis in the Eastern Amazon. Revista Ciência Agronômica 47, 56-68.

Pinto RA, Yamamoto PT, Paiva PEB, Gravena S, 1995. Amostragem seqüencial de pragas na citricultura como método rápido e seguro. Laranja 16, 133-48.

Rodrigues JCV, 1995. Leprose dos Citros, Cito-histopatologia, Transmissibilidade e Relação com o Vetor Brevipalpus phoenicis Geijskes (Acari: Tenuipalpidae). Piracicaba, Brazil: Centro de Energia Nuclear na Agricultura, Masters dissertation.

Rodrigues JCV, Nogueira NL, Prates HS, Freitas DS, 1994. Leprose dos citros: importância, histórico, distribuição e relações com o ácaro vetor. Laranja 15, 123-38.

Rodrigues JCV, Nogueira NL, Müller GW, Machado MA, 2000. Yield damage associated with citrus leprosis on sweet oranges. In: Proceedings of the International Society of Citriculture Congress. UC Riverside, CA, USA: International Society of Citriculture, 151-2.

Rossetti V, Colariccio A, Chagas CM, Sato ME, Raga A, 1997. Leprose dos citros. Boletim Técnico do Instituto Biológico 6, 5-27.

Roy A, Stone AL, Shao J et al., 2015. Identification and molecular characterization of nuclear Citrus leprosis virus, a member of the proposed Dichorhavirus genus infecting multiple Citrus species in Mexico. Phytopathology 105, 564-75.

Salva RA, 1994. Prática do monitoramento de MIP - Citros no Brasil. In: Anais Seminário Internacional de Citros, Bebedouro, 255-67.

Sánchez-Velázquez EJ, Santillán-Galicia MT, Novelli VM, 2015. Diversity and genetic variation among Brevipalpus populations from Brazil and Mexico. PLoS ONE 10, e0133861.

Tassi AD, Garita-Salazar LC, Amorim L et al., 2017. Virus-vector relationship in the citrus leprosis pathosystem. Experimental and Applied Acarology 71, 227-41.

\section{Supporting Information}

Additional Supporting Information may be found in the online version of this article at the publisher's web-site.

Figure S1. Experimental areas showing the Valencia plot of 1160 trees distributed in 20 rows containing 58 trees each and the Natal plot of 720 trees distributed in 24 rows containing 30 trees each. The arrow indicates the prevailing wind direction in the area.

Figure S2. Maps of incidences of infested trees with Brevipalpus yothersi (a) and trees with leprosis symptoms (b) in plots of Valencia during 2002, 2003 and 2004. The rectangle represents the monitoring plot and the black points correspond to trees with mite presence (a) or disease symptoms (b).

Figure S3. Maps of incidence of infested trees with Brevipalpus yothersi (a) and trees with leprosis symptoms (b) in plots of Natal during 2002, 2003 and 2004. The rectangle represents the monitoring plot and the black points correspond to trees with mite presence (a) or disease symptoms (b). 